\title{
Community-based erosion control model in Batur Lake zone
}

\author{
I Made $\mathrm{Nada}^{1 *}$, I Wayan Redana ${ }^{2}$, I G B Sila Dharma $^{2}$, and $A$ A Gde Agung Yana ${ }^{2}$ \\ ${ }^{1}$ Department of Engineering, Doctoral Program Universitas Udayana, Denpasar, Indonesia \\ ${ }^{2}$ Department of Civil Engineering, Universitas Udayana, Denpasar, Indonesia
}

\begin{abstract}
Erosion control in Lake Batur area is community-based directed to maintain lake balance. The aims of this research is: 1) to obtain a community-based erosion control model, 2) to analyze the role of communities in the application of land management models, 3) to analyze other plant species in collaboration with the arrangement model, and 4) to analyze the impact of terraces blooming against sedimentation. This research is field experiments and surveys, and the sampling was conducted by purposive sampling with 64 samples. The socio-economic support data of the community was determined by 180 respondents by cluster sampling. Interviews and questionnaires were conducted through closed questions on a conventional scale. The characteristics of the lake were analyzed statistically and descriptively by using the SPSS tool. Land mapping was conducted by GPS method with GIS device. Prediction of erosion was by using USLE Model, while sedimentation was measured by the Stanford Sediment model. The analysis shows that the increase of settlement is averagely of $115.85 \%$, plantation is $245.50 \%$ and the sedimentation level is $1,017,93 \mathrm{~m}^{3} /$ year. Conclusions and outcomes were in the form of community-based terracing model that collaborate with elephant grass and vetiveria plants.
\end{abstract}

\section{Introduction}

The condition of Lake Batur's water volume in Bali continues to decline, the depth of the lake continues to experience siltation, the quality of the lake water continues to decrease and the fertility of the water increases. The process of erosion, sedimentation, and silting of the lake was triggered by the management pattern of agricultural land on the edge of the lake that does not pay attention to the aspects of soil and water conservation. Mining activities located in the area around Lake Batur is mining class $\mathrm{C}$ of sand excavation material. The location of sand mining is in the Village of Songan A. On one hand, this activity will be able to increase the income of the people. Regarding the environment, it is very detrimental to the landscape, let alone the mining system is not well planned, so it is easy to cause landslides, such as that occurred on February $9^{\text {th }}, 2017$, that claimed casualties, or create new puddles with mild to severe erosions.

\footnotetext{
* Corresponding author: nada brm@yahoo.com
} 
Land damage occurs mostly on dry land, especially on land planted with food crops, and smallholder plantations. Damage occurs, among others, because the dry land is open for the processing of soil, burning, weeding, and grazing so that the soil easily eroded and landslides. Erosion and flooding can degrade the quality and quantity of natural resources and water so that the productivity of these resources keep on decreasing. The purposes of this research are: 1) to obtain a model of community-based erosion control, 2) to analyze the role of the community in the application of land management model in the lake area, 3) ti analyze the types of plants that were collaborated with the arrangement model in the lake area, 4) to compare the land arrangement of expanded terracing model and non-expanded terracing model. The target to be achieved is a community-based expanded terracing model to be incorporated with elephant grass and vetiver.

\section{Literature review}

\subsection{Erosion}

Erosion produces sediment, a pollutant that can degrade the quality and quantity of water, especially it affects physical, biological and chemical characteristics in waters [1]. In general, the occurrence of erosion is determined by climatic factors (especially rain intensity), topography, soil characteristics, vegetation, and land use.

To find out the magnitude of erosion caused by land conversion, it is used the erosion prediction. The prediction of erosion from a plot of land is a method to estimate the rate of erosion that will occur from specific land use and management [2]. If the rate of erosion that is to happen has been predicted and the rate of erosion that can still be tolerated can be determined, it can be determined the policy of land use so that no soil damage and it can be used productively and sustainably. The designated land uses are those that can suppress the rate of erosion to be equal to or less than the tolerable rate of erosion. According to [3], the longer and steeper the slopes, the higher the causal factor of erosion. The core method will provide smaller erosion value compared to compaction and smoothing methods [4].

\subsection{Rainfall}

Rainfall is a climatic factor that affects erosion. The amount of rainfall, intensity, and distribution of rain determines the strength of rain dispersion to the soil, the amount, speed of surface flow, and erosion damage. Maximum rainfall in an area according to Central Meteorology and Geophysics Center (BMG) of $531 \mathrm{~mm}$ per month that occurred in March. In this process, the leveling of the rain using the average method of algebra from the daily rainfall data of rainfall recording results from the area of each post station of rain recorder.

$$
R=\frac{1}{N}\left(R_{1}+R_{2}+\ldots .+R_{n}\right)
$$

where $R=$ Regional rainfall, $R_{l}+R_{2}+\ldots+R_{n}=$ Rainfall at each observation point, $N$ $=$ Number of observation points.

\subsection{Erosion prediction according to Universal Soil Loss Equation (USLE)}

Predicting erosion is essential to evaluate whether potential erosion and actual erosion will damage the land, and this data can be used as a plan and prioritized management of the land. Besides, it can also be used to evaluate the results that have been applied whether it is 
under the soil conditions. The Universal Soil Loss Equation (USLE) model is a further empirical model for calculating surface erosion and gully. Murtiono [5] states that based on research results, the USLE model can be applied in the tropics, and USLE estimates can be used to take practical action to control erosion. If the estimation results are higher than allowed, then it is necessary to take the action of plant management and soil conservation. The prediction of the magnitude of erosion uses the Universal Soil Loss Equation (USLE) that is mathematically formulated as follows:

$$
A=R K L S C P
$$

where $A=$ the amount of soil erosion or the amount of soil loss (ton/ha/y), $R=$ rainfall erosivity factor index, $K=$ soil erodibility factor index, $L S=$ index of length and slope factor, $C=$ index of plant management factors, $P=$ index of soil conservation techniques.

\subsection{Terracing model structuring}

The calculation of terracing used terrace theory is a structure for soil and water conservation mechanically designed to shorten the length of the slope and/ or minimize the slope by extracting and sloping the slopes. The purpose of making the terrace is to reduce the speed of runoff and expand the water absorption, so that the loss of soil may be reduced [6]. In this study, terracing is designed variably, so it is expected to provide the right design choice for the slope. Slope variation is the variation of the groundwater position, the increase of live load, and the terracing variation which is expected to be able to find out the result of the analysis, the effective, and efficient design for the planning of the slope. The slope analysis used simplified Bishop method as shown in Eq. 3.

$$
F=\frac{\sum_{I=1}^{I=1 / 2}\left[c b i+\left(W_{i}\right)(1-r u) \tan \varphi\right]\left\{\frac{1}{\cos \varphi(1+\tan \varphi \tan \varphi / F)}\right\}}{\sum_{i=1}^{i=1 / 2} W i \sin \varphi}
$$

where $F=$ safe factor, $\phi=$ angle $\left(^{\circ}\right), C=$ effective soil cohesion $\left(\mathrm{kN} / \mathrm{m}^{2}\right), b_{i}=$ width of the first section, $m W_{i}=$ the weight of the first section of soil $(\mathrm{kN}), \phi i=$ the effective friction angle $\left({ }^{\circ}\right), U_{i}=$ the pore pressures of the first section $\left(\mathrm{kN} / \mathrm{m}^{2}\right), r u=$ the ratio of pore water pressure. This Bishop method uses a trial and error, but the results are more accurate, to facilitate the calculation, it can be used the value of Mi function as in Eq. 4.

$$
\mathrm{M}_{i}=\cos \phi\left(1+\operatorname{tg} \phi_{i} \operatorname{tg} \varphi / F\right)
$$

where $F=$ safe factor, $\varphi=$ the effective friction angle $\left(^{\circ}\right), \phi=$ angle $\left({ }^{\circ}\right)$.

\section{Research methods}

\subsection{Research design}

The research that will be conducted is field experiment, field survey about land condition from lake area, research on biophysical conditions of the research location, i.e. type, structure, and texture of soil: morphology or topography of the length of the slope, geological/ geophysical properties of the land, vegetation: climates, i.e. rainfall, and rain intensity, vegetation and non-vegetation land mapping and eroded land mapping and this is 
done with GPS (Geographic Positioning System) with GIS (Geographic Information System) device and surveys on community participation in the erosion control.

\subsection{Research sites and data sources}

The research was conducted in Batur Lake area in Bangli regency. This research is field experiment, survey research, and sampling is done by purposive sampling of 64 samples. The supporting data on the socio-economic of the people was determined by 180 respondents by cluster sampling in the Lake area. Interviews and questionnaires are closed questions on a conventional scale (1 to 10$)$.

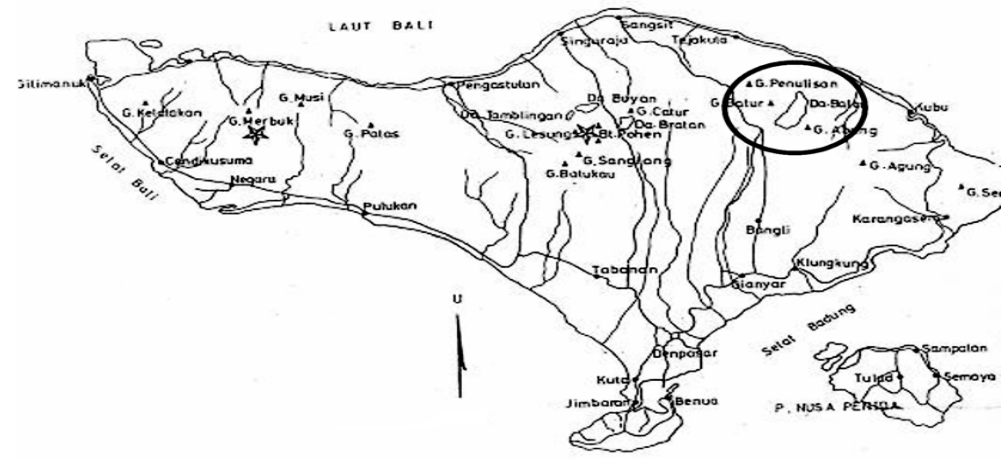

Fig. 1. Research sites in the Batur Lake area (circle).

\subsubsection{Primary data}

The data collected consists of soil physical properties, and field survey. Soil physical consisting of the weight of soil volume, texture, organic matter content, structure, and permeability of soil (to determine the value of soil erodibility). The weight of soil volume, texture, and soil organic matter content was done by analysis in soil laboratory at the Faculty of Agriculture of Udayana University, for measurement of soil properties, soil texture is analyzed by pipette, Bulk density by sample ring, permeability is measured by permeameter, organic material by Walkley and black. The field surveys conduct soil sampling in four lakes, both on the banks and the lake. The depth of the soil is measured by using a soil drill, a soil conservation effort that is applied either technically or vegetatively to reduce soil erosion and to determine the value of soil conservation factor $(\mathrm{P})$.

\subsubsection{Secondary data}

Secondary data are data obtained from related land use information including a) rainfall data to calculate rainfall erosion value include the average rainfall, the average number of rainy days of rainfall of max 24 hours, b) administrative map, topographic map, soil type map, land use map, and vegetation covering map.

\subsection{Data source}

Sources of data in this study include: a) Data from the Bali Provincial Forestry Service on the administrative map of the study area, b) the District Planning Office, c) Precipitation Stations, d) Central River Region in Bali, Nusa Penida. 


\section{Results and discussion}

The existing data could be seen in Table 1. The survey results that have been done show that the population growth and rapidly increasing tourism activities in the area around Lake Batur often pose complex problems that require intensive management. Land use, sedimentation data, measurement, physical and topography of the Lake Batur are presented in Table 2-5. These problems will result in a decrease in lake water quality, eutrophication potential (increased water fertility), siltation that will alter the entire lake ecosystem. A large number of local people who use the lake border as land for agriculture. At the time of the lake water receded, people directly planted land that is not inundated with lake water with horticultural plants. As a result, when the lake water overflows, the land is submerged, and the fertilizer contained in the soil will be mixed with the lake water so that the water quality will decrease.

Table 1. Existing condition of Lake Batur [7].

\begin{tabular}{|c|c|}
\hline Description & Notes \\
\hline Location & Kintamani Sub - District, Bangli Regency \\
\hline Geographical location & $\begin{array}{r}115^{\circ} 22^{\prime} 42^{\prime} \text { ' }-115^{\circ} 25^{\prime} 33 \text { East Longitude } \\
8^{\circ} 17^{\prime} 14^{\prime} \text { ' } 8^{\circ} 13^{\prime} 19 \text { South Latitude }\end{array}$ \\
\hline Annual rainfall & $1.809 \mathrm{~mm}$ \\
\hline Lake water front evaluation & $1.032 \mathrm{~m}$ asl \\
\hline Lake type & Caldera Lake \\
\hline Water type & Natural lake \\
\hline Depth (max.) & $80 \mathrm{~m}$ \\
\hline Surface area of lake & $16,213 \mathrm{~km}^{2}$ \\
\hline Volume of the lake & $773.33 \mathrm{~m}^{3}$ \\
\hline Inlet (inflow) & Only from DTA \\
\hline Outlet (outflow) & not available \\
\hline
\end{tabular}

Aside from being a source of raw water for drinking water, water from Lake Batur is also for activities vegetable gardens that surround the lake. Various vegetable commodities grown include onions, cabbage, tomatoes, and chili. Vegetable farmers around Batur lake suck water directly from the lake. By using pipes or water hoses that are up to several kilometers long, they suck the water of Lake Batur to water their garden at the foot of Mount Batur. This indirectly results in the volume of lake water being significantly reduced.

Lake Batur is one of the territorial waters that is utilized by people other than fisheries, as well as a center for aquaculture activities. The dominant fishing gear used in Lake Batur is gill net. The cultivation system used is Karamba a floating net cage. The number of fish cages in the lake Batur makes the surrounding people provide an excessive fish feed that makes the quality of water in lake Batur become polluted because of the fish feed.

Mining activities located in the area around Lake Batur is sand mining class C. The sand mining is located in the village of Songan A. On one hand this activity will be able to 
increase people's incomes but in terms of environment, it is very damaging to the landscape, let alone the system of mining is not regulated correctly, so it is easy to cause landslides or create new puddle areas. The erosion level is classified into mild to severe. Thus, for locations that are classified as experiencing severe erosion will accelerate the silting of lakes, which in turn reduces the capacity of the lake to hold the water.

Table 2. Land use in lake area [7].

\begin{tabular}{|c|c|c|c|}
\hline Description & $\mathbf{1 9 9 9}(\mathbf{H a})$ & $\mathbf{2 0 0 9}(\mathbf{H a})$ & $\mathbf{2 0 1 5}(\mathbf{H a})$ \\
\hline Field & 1634.07 & 536.67 & 636.67 \\
\hline High density natural forests & 608.65 & 228.56 & 228.56 \\
\hline $\begin{array}{c}\text { Natural forest with medium } \\
\text { density }\end{array}$ & 260.85 & 533.32 & 433.32 \\
\hline Settlement & 1435.20 & 2217.00 & 2342.00 \\
\hline Plantation & 144.89 & 529.22 & 529.22 \\
\hline Shrubs & 312.34 & 383.23 & 258.23 \\
\hline Geopark & 1066.00 & 1034.00 & 1034.00 \\
\hline
\end{tabular}

Table 3. Sedimentation of Lake Batur [7].

\begin{tabular}{|c|c|c|}
\hline Lake Morphometry & in 2013 & in 2015 \\
\hline width of the waters $\left(\mathrm{km}^{2}\right)$ & 14.71 & 16.55 \\
\hline Size of the waters (ha) & 1471 & 1655 \\
\hline Water volume (million $\left.\mathrm{m}^{3}\right)$ & 820.54 & 773.33 \\
\hline Maximum water depth (m) & 88 & 80 \\
\hline Sedimentation (m³) & & 5980.47 \\
\hline Period (year) & & 3 \\
\hline Sedimentation rate (m³/year) & & 1993.49 \\
\hline
\end{tabular}

Table 4. Measurement results of lake area [7].

\begin{tabular}{|c|c|c|c|}
\hline \multirow{2}{*}{ Description } & \multicolumn{3}{|c|}{ Sizes (Ha) } \\
\cline { 2 - 4 } & $\mathbf{1 9 9 9}$ & $\mathbf{2 0 0 9}$ & $\mathbf{2 0 1 5}$ \\
\hline Lake Batur & 1661 & 1630.4 & 1621.3 \\
\hline Lake Beratan & 394.41 & 386 & 376.4 \\
\hline Lake Buyan & 439 & 413.15 & 476.6 \\
\hline Lake Tamblingan & 146.6 & 143.50 & 146.1 \\
\hline
\end{tabular}


Table 5. Physical condition and topography of Lake Batur [7].

\begin{tabular}{|c|c|c|}
\hline Description & Physical condition & Topography \\
\hline North & $\begin{array}{l}\text { Settlements, farming, animal } \\
\text { husbandry, Ulun Danu Batur Temple }\end{array}$ & \multirow{4}{*}{$\begin{array}{l}\text { The slope of the flat } \\
\text { slopes with a } \\
\text { steepness of less than } \\
3 \% \text { is only located in } \\
\text { Kedisan and Buahan } \\
\text { Villages while the } \\
\text { other villages are } \\
\text { bumpy to steep ( } 8 \% \text { - } \\
>65 \% \text { ) }\end{array}$} \\
\hline East & $\begin{array}{l}\text { Hills, unspoiled forests, bottom slope } \\
\text { of settlements, farming, and Trunyan } \\
\text { Grave tours }\end{array}$ & \\
\hline South & Settlement, restaurant, and pier & \\
\hline West & $\begin{array}{l}\text { Tourist attractions, temple, and the } \\
\text { sand mining }\end{array}$ & \\
\hline
\end{tabular}

The locations around Songan A and B then around Kedisan to Buahan Villages generally have a wide litoral zone with the dominant type of waters of muddy sand. These sites experience relatively high levels of sedimentation. Factors of use and management of land around the lake have a significant effect on sedimentation levels in the lake. The use of land for horticultural agriculture with the use of organic fertilizers with high volume and intensity causes very high sedimentation rate brought by surface runoff during the rainy season.

The results of slope/topographic (LS) mapping with the GPS method and GIS devices indicate the nature of the slope can affect the amount of energy that causes erosion is seen in Table 6. The slope properties are slope, slope length and slope shape. Slope affects the speed and volume of surface runoff, the steeper the slope the higher the slope and the faster the runoff rate. The shorter the time for infiltration, the greater the volume of runoff. Thus the erosion that occurs is getting bigger.

Table 6. Topographic Factor Value (LS) in Lake Batur Region

\begin{tabular}{|c|c|c|c|}
\hline $\begin{array}{c}\text { Land } \\
\text { unit }\end{array}$ & $\begin{array}{c}\text { Slope length } \\
(\mathbf{m})\end{array}$ & Slope (\%) & $\begin{array}{c}\text { Topographic factor values } \\
\text { (LS) }\end{array}$ \\
\hline 1 & 98 & 65.4 & 64.8 \\
\hline 2 & 67 & 45.3 & 26.9 \\
\hline 3 & 65 & 48.7 & 30.3 \\
\hline 4 & 57 & 42.1 & 21.6 \\
\hline 5 & 64 & 3.4 & 0.5 \\
\hline 6 & 68 & 5.6 & 0.9 \\
\hline 7 & 56 & 4.5 & 0.6 \\
\hline
\end{tabular}

Community land use patterns, especially in land management that change land cover, can result in surface erosion at varying levels or quantities. The amount of erosion that takes place is determined by the intensity and form of land processing activities. Erosion prediction in the Lake Batur region uses the USLE model could be seen in Table 7. 
Table 7. Erosion prediction in the Lake Batur region.

\begin{tabular}{|c|c|c|c|c|c|c|}
\hline $\begin{array}{c}\text { Land } \\
\text { units }\end{array}$ & $\begin{array}{c}\text { Rainy } \\
\text { Erosion } \\
\text { (R) }\end{array}$ & $\begin{array}{c}\text { Soil } \\
\text { Erodibilas } \\
\text { (K) }\end{array}$ & $\begin{array}{c}\text { Topographic } \\
\text { factors (LS) }\end{array}$ & $\begin{array}{c}\text { Plant } \\
\text { factors } \\
\text { (C) }\end{array}$ & $\begin{array}{c}\text { Soil and } \\
\text { water } \\
\text { conservation } \\
\text { action factor } \\
\text { (P) }\end{array}$ & $\begin{array}{c}\text { Value of } \\
\text { soil } \\
\text { erosion (E) } \\
\text { (ton/ha/th) }\end{array}$ \\
\hline 1 & 4.5 & 6.3 & 64.8 & 0.02 & 1 & 36.6 \\
\hline 2 & 4.5 & 6.3 & 26.9 & 0.02 & 1 & 15.1 \\
\hline 3 & 4.5 & 6.2 & 30.3 & 0.02 & 1 & 16.9 \\
\hline 4 & 4.5 & 6.4 & 21.6 & 0.02 & 1 & 12.4 \\
\hline 5 & 4.5 & 6.3 & 0.5 & 0.7 & 1 & 10 \\
\hline 6 & 4.5 & 6.5 & 0.9 & 0.7 & 1 & 18.5 \\
\hline 7 & 4.5 & 6.4 & 0.6 & 0.7 & 1 & 12.8 \\
\hline
\end{tabular}

\section{Conclusions}

Along the banks of Lake Batur are used for agricultural land, the waters are used for recreation, and fish farming. During the rainy season in the lake area occurs, material drift due to agricultural activities and sand mining. All the waterfront of the lake rises that inundated the agricultural land so that the fertilizer used to flow into the lake, so the lake becomes polluted and sedimentation continues to increase per year. To reduce erosion and sedimentation in the lake, a community-based terraced landscaping model that collaborates with elephant grass and vetiver was used.

\section{References}

1. C. Asdak, Hidrologi dan pengelolaan daerah aliran sungai (Gadjah Mada University Press, Yogyakarta, 1995)

2. S. Arsyad, Konservasi tanah dan air (Penerbit IPB Press, Bogor, 1989)

3. I.W.S. Adnyana, AGRITROP Jurnal Ilmu-ilmu Pertanian 20, 1 (2001)

4. A.T. Mandagi, F.J. Manoppo, Pertemuan Ilmiah Tahunan-XIII HATTI (2009)

5. U.H. Murtiono, Forum Geografi (2008)

6. P.D. Apriliana, S. As'ad, N.S. Surjandari, Jurnal Matriks Teknik Sipil 2, 1 (2014)

7. BWS Bali-Penida. Studi evaluasi dan perencanaan pemanfaatan empat danau di Provinsi Bali. (PT Rancang Semesta Nusantara, Denpasar, 2015) 